\title{
A função normativa das Agências Reguladoras: análise legislativa e doutrinária*
}

\author{
Carla Fernanda Martins ${ }^{* *}$
}

\section{INTRODUÇÃO}

Nos últimos anos, principalmente a partir de 1995, quando foi criado o Ministério da Administração Federal e Reforma do Estado, foi dado impulso a uma revisão das formas de organização e funcionamento do Estado brasileiro, com a proposição, pelo governo federal, de uma ampla reforma gerencial, elaborada pelo Ministro Luiz Carlos Bresser Pereira e sua equipe. Dentre as medidas adotadas para a reconstrução e fortalecimento do Estado, está a criação das agências reguladoras, mediante lei, sob a forma de autarquias de regime especial, com personalidade jurídica de Direito Público e autonomia patrimonial, administrativa e financeira, cuja função principal é a regulação da atividade econômica e dos serviços públicos prestados pelo próprio Estado ou por particulares, através da normatização, fiscalização e controle de atividades exercidas por particulares.

O exercício dessas funções pelas agências reguladoras tem gerado grandes controvérsias, principalmente no que diz respeito ao exercício de poderes normativos pelas agências, ocasionando grandes discussões na doutrina brasileira, que está longe de atingir um consenso. Passemos, pois, a um exame mais apurado acerca da atribuição de funções normativas às agências.

\footnotetext{
"Texto utilizado como base para a monografia intitulada "A Função Normativa das Agências Reguladoras nos Estados Unidos e no Brasil”, apresentada em 22-07-2005 como parte dos requisitos para a obtenção do grau do Curso de Ciências Jurídicas e Sociais da Universidade Federal do Rio Grande do Sul.

"* Bacharel em Ciências Jurídicas e Sociais pela Universidade Federal do Rio Grande do Sul.
} 


\section{DISTINÇÃO ENTRE} REGULAR E REGULAMENTAR

Para compreender a função normativa das agências reguladoras, é necessário distinguir dois termos que não se confundem: regular e regulamentar.

No Brasil, o termo regulação surgiu com o movimento de Reforma do Estado, principalmente quando, em decorrência da privatização de empresas estatais e da introdução da idéia de competição entre delegatárias na prestação de serviços públicos, entendeu-se necessário regular as atividades objeto de delegação a empresas privadas, para garantir a regularidade na prestação de serviços e o funcionamento equilibrado da concorrência. Em nosso ordenamento jurídico, o vocábulo regulação surgiu a partir da própria Constituição, com a introdução da expressão "órgão regulador" nos artigos 21 , inciso $\mathrm{XI}$, e $177, \S 2^{\circ}$, inciso III, e também do papel regulador atribuído ao Estado no artigo 174. ${ }^{1,2}$

O conceito de regulação pode assumir vários sentidos. Em uma perspectiva mais ampla pode-se considerar a regulação como toda forma de intervenção do Estado na economia, independentemente dos seus instrumentos e fins, abrangendo tanto a intervenção direta como a indireta. Num sentido mais restrito, regulação é a coordenação e disciplina da atividade econômica privada, excluindo-se a intervenção direta do Estado na economia. $^{3}$

Para Di Pietro, regular significa estabelecer regras, independentemente de quem as dite, seja o Legislativo ou Executivo, ainda que por meio de órgãos da Administração Direta ou entidades da Administração Indireta. Trata-se de vocábulo de sentido amplo, que abrange, inclusive, a regulamentação, que tem um sentido mais estrito. ${ }^{4}$

1 DI PIETRO, Maria Sylvia Zanella. Limites da Função Reguladora das Agências diante do Princípio da Legalidade. In: DI PIETRO, Maria Sylvia Zanella (Org.). Direito Regulatório. Belo Horizonte: Fórum, 2003. p. 28.

2 Artigo 21. Compete à União: [...] XI-explorar, diretamente ou mediante autorização, concessão ou permissão, os serviços de telecomunicações, nos termos da lei, que disporá sobre a organização dos serviços, a criação de um órgão regulador e outros aspectos institucionais; [...]. Artigo 174. Como agente normativo e regulador da atividade econômica, o Estado exercerá na forma da lei, as funções de fiscalização, incentivo e planejamento [...] Artigo 177 (...) $\S 2^{\circ}$ A lei a que se refere o $\S 1^{\circ}$ disporá sobre: (...) III - a estrutura e atribuições do órgão regulador do monopólio da União. [...] (BRASIL. Constituição da República Federativa do Brasil, de 05 de outubro de 1988. Disponível em: $<$ http://www.planalto.gov.br>Acesso em: junho/2005).

3 CARVALHO, Vinícius Marques. Desregulação e Reforma do Estado no Brasil: impacto sobre a prestação de serviços públicos. In: DI PIETRO, Maria Sylvia Zanella (Org.). Direito Regulatório. Belo Horizonte: Fórum, 2003. p. 158.

4 DI PIETRO, Maria Sylvia Zanella. Parcerias na Administração Pública. 4. ed. São Paulo: Atlas, 2002.p. 150. 
Relativamente ao termo regulamentar, Hely Lopes Meirelles entende que esse é um poder de que dispõem os Chefes do Executivo (Presidentes da República, Governadores e Prefeitos) de explicar a lei para a sua correta execução, ou de expedir decretos autônomos sobre matéria de sua competência ainda não disciplinada por lei. Afirma que tal poder é inerente e privativo do Chefe do Executivo, e, por isso mesmo, indelegável. Ressalta que o regulamento não é lei, embora a ela se assemelhe no conteúdo e poder normativo. ${ }^{5}$

Leila Cuéllar, numa definição mais ampla, afirma que regulamentar é uma espécie de ato administrativo que gera uma norma jurídica geral e abstrata, emanada da Administração Pública, que tem por finalidade o regular exercício da função administrativa, bem como a execução de lei cuja efetividade demande ação administrativa. ${ }^{6}$

Cumpre ainda ressaltar que, de acordo com Luís Roberto Barroso, embora se associe a função reguladora com o desempenho de competências normativas, seu conteúdo é mais amplo e variado, pois, ainda quando se aproxime, eventualmente, da idéia de poder de polícia administrativa-poder de direcionar as atividades privadas de acordo com interesses públicos juridicamente definidos -, a regulação contempla uma gama mais ampla de atribuições, relacionadas ao desempenho de atividades econômicas e à prestação de serviços públicos, incluindo sua disciplina, fiscalização, composição de conflitos e aplicação eventual de sanções. Afirma que, às agências reguladoras tem sido cometido um conjunto diversificado de tarefas, dentre as quais se incluem, a despeito das peculiaridades de cada uma delas, em função da diversidade de textos legais, as seguintes: a) controle de tarifas, de modo a assegurar o equilíbrio econômico e financeiro do contrato firmado entre a Administração e o delegatário; b) universalização dos serviços, estendendo-os a parcelas da população que deles não se beneficiavam por força da escassez de recursos; c) fomento da competitividade, nas áreas nas quais não haja monopólio natural; d) fiscalização do cumprimento do contrato de concessão; e e) solução arbitral dos conflitos entre as

5 MEIRELLES, Hely Lopes. Direito Administrativo Brasileiro. 29. ed. atual. por Eurico de Andrade Azevedo, Delicio Balesteto Aleixo e José Emmanuel Burle Filho. São Paulo: Malheiros, 2004, p. 125-6.

6 CUELLAR, Leila apud GUERRA, Glauco Martins. Agências Reguladoras no Brasil: princípio da legalidade e regulação. In: DI PIETRO, Maria Sylvia Zanella (Org.). Direito Regulatório. Belo Horizonte: Fórum, 2003, p. 30. 
diversas partes envolvidas: consumidores do serviço, poder concedente, concessionários, a comunidade como um todo, os investidores potenciais, etc.?

Feita a distinção entre esses dois vocábulos, cabe agora analisar quais foram as funções normativas atribuídas às agências reguladoras pelo legislador pátrio.

\section{ANÁLISE LEGISLATIVA}

Inicialmente, será feito um breve estudo das leis instituidoras das agências reguladoras e sobre a competência legislativa que lhes foi atribuída.

$O$ artigo $2^{\circ}$ da Lei ${ }^{\circ} 9.427 / 96$, que cria a Agência Nacional de Energia Elétrica - ANEEL, dispõe que a entidade tem por finalidade regular e fiscalizar a produção, transmissão, distribuição e comercialização de energia elétrica, em conformidade com as políticas e diretrizes do governo federal, prevendo, no artigo $3^{\circ}$, inciso XIX, que é sua atribuição regular o serviço concedido, permitido e autorizado e fiscalizar permanentemente sua prestação. ${ }^{8}$

A Lei 9.478/97, editada com base no artigo $177, \S 2^{\circ}$, inciso III, da Constituição Federal, ${ }^{9}$ institui, em seu artigo $7^{\circ}$, a Agência Nacional do Petróleo, Gás Natural e Biocombustíveis - ANP,${ }^{10}$ como órgão regulador da indústria do petróleo, gás natural, seus derivados e biocombustíveis, vinculada ao Ministério de Minas e Energia. Em seu artigo $8^{\circ}$, o referido diploma legal atribui à ANP a função de promover a regulação, a contratação e a fiscalização das atividades econômicas integrantes da indústria do petróleo, do gás natural e dos biocombustíveis, especificando em seus incisos as hipóteses em que a ANP promoverá essa regulação. ${ }^{11}$

A Lei n ${ }^{\circ} 9.472 / 97$, com respaldo no artigo 21, inciso XI, da Constituição Federal, ${ }^{12}$ cria, em seu artigo $8^{\circ}$, a Agência Nacional de Telecomunicações, com a função de órgão regulador das telecomunicações. ${ }^{13}$ Em seu artigo 19, estatui a referida

7 BARROSO, Luís Roberto. Agências Reguladoras. Constituição, Transformações do Estado e Legitimidade Democrática. In: MOREIRA NETO, Diogo de Figueiredo (Coord.). Uma Avaliação das Tendências Contemporâneas do Direito Administrativo. Rio de Janeiro: Renovar, 2003. p. 179.

8 BRASIL. Lei $n^{\circ} 9.427 / 96$, de 26 de dezembro de 1996. Disponível em: <http:// www.planalto.gov.br>. Acesso em: jun. 2005.

9 BRASIL. Constituição da República Federativa do Brasil, de 05 de outubro de 1988. Disponível em: <http://www.planalto.gov.br > Acesso em: junho/2005.

10 Ibidem.

11 BRASIL. Lei $\mathrm{n}^{\circ}$ 9.478/97, de 06 de agosto de 1997. Disponível em: <http:// www.planalto.gov.br>. Acesso em: junho/2005.

12 BRASIL. Constituição da República Federativa do Brasil, op. cit.

13 Ibidem. 
lei as competências da agência, incluindo, dentre elas, a atribuição de expedir normas que disponham sobre: a) outorga, prestação e fruição dos serviços de telecomunicação no regime privado; b) prestação de serviços de telecomunicação no regime privado; c) padrões a serem cumpridos pelas prestadoras de serviços de telecomunicações quanto aos equipamentos que utilizarem, e d) padrões que assegurem a compatibilidade, a operação integrada e a interconexão entre as redes, abrangendo, inclusive, os equipamentos terminais. ${ }^{14}$

A Lei n ${ }^{\circ} 9.961 / 00$ institui a Agência Nacional de Saúde Suplementar ANS, como órgão de regulação, normatização, controle e fiscalização das atividades que garantam a assistência suplementar à saúde, definindo as competências da agência em seu artigo $4^{\circ}$, dentre as quais destacamos: a) estabelecer normas para ressarcimento ao Sistema Único de Saúde - SUS; b) editar normas relativas à adoção e utilização, pelas operadoras de planos de assistência à saúde, de mecanismos de regulação do uso dos serviços de saúde; c) normatizar os conceitos de doença e lesão preexistentes; d) expedir normas para registro dos produtos definidos no inciso $I$ e no $\S 1^{\circ}$ do artigo $1^{\circ}$ da Lei no 9.656, de 1998 ; e) estabelecer normas, rotinas e procedimentos para concessão, manutenção e cancelamento de registro dos produtos das operadoras de planos privados de assistência à saúde; e e) expedir normas e padrões para o envio de informações de natureza econômico-financeira pelas operadoras, com vistas à homologação de reajustes e revisões. ${ }^{15}$

E, finalmente, a Lei $n^{\circ}$ 9.984/00, cria a Agência Nacional de Águas ANA, cabendo-lhe disciplinar, em caráter normativo, a implementação, a operacionalização, o controle e a avaliação dos instrumentos da Política Nacional de Recursos Hídricos. ${ }^{16}$

Analisando-se o disposto nas leis de criação dessas agências reguladoras, verifica-se que em todos os casos o legislador previu a competência para expedir normas destinadas a regular as atividades do setor em que atuam. No entanto, apenas duas agências possuem assento constitucional, visto que a Constituição Federal prevê a criação de órgãos reguladores somente para o monopólio do petróleo (art. 177, § $2^{\circ}$, III) e para os serviços de telecomunicação (art. 21, XI).

Examinada a atribuição de poderes normativos feita às agências reguladoras pelas suas leis de criação,

14 BRASIL. Lei $n^{\circ} 9.472 / 97$, op. cit.

15 BRASIL, Lei $n^{\circ} 9.961 / 00$, de 28 de janeiro de 2000. Disponível em: <http:// www.planalto.gov.br>. Acesso em: junho/2005.

16 BRASIL. Lei $\mathrm{n}^{\circ} 9.984 / 00$, de 17 de julho de 2000. Disponível em: <http:// www.planalto.gov.br>. Acesso em: junho/2005. 
analisaremos a seguir a posição da doutrina a respeito do tema.

\section{ANÁLISE DOUTRINÁRIA}

\subsection{Maria Sylvia Zanella Di Pietro}

Afirma a autora que existem sérias incertezas quanto aos limites da função reguladora, principalmente no que diz respeito ao estabelecimento de normas gerais e abstratas. Tal dificuldade decorre do fato de que essa função vem sendo atribuída a órgãos e entidades, sem expressa previsão constitucional. ${ }^{17}$

Maria Sylvia sustenta que há dois aspectos em conflito: de um lado, a consciência da necessidade de reconhecer poder normativo a órgãos e entidades da Administração Pública, seja pela idéia de especialização inspiradora de sua criação, seja pelo modismo e globalização que levam à imitação do direito estrangeiro, de outro lado, está o fato de que a Constituição definiu as competências normativas exaustivamente, não deixando espaço para outras entidades não expressamente referidas. ${ }^{18,19}$

Ademais, acrescenta que, relativamente à função normativa de órgãos administrativos, a Constituição brasileira não deixou espaço para o seu exercício a não ser em casos excepcionais: a) no artigo 25 do ADCT, revogou, no prazo de 180 dias a contar da vigência da própria Constituição, todas as normas que outorgavam função normativa a órgãos do Poder Executivo, deixando uma abertura para a possibilidade de prorrogação do prazo das leis que conferiam essa atribuição, e, em função das agências reguladoras terem sido criadas posteriormente à Lei Maior, não foram alcançadas por essa

17 DI PIETRO, Limites da Função..., p. 51.

18 Ibidem, p. 51.

19 Ressalte-se que a Constituição estabeleceu as competências legislativas do Congresso Nacional em seu artigo 48, abrangendo todas as matérias de competência da União; em seu artigo 59 definiu as espécies normativas igualmente de forma exaustiva; determinou regras sobre participação dos demais Poderes no processo de elaboração das leis, especialmente no que diz respeito à iniciativa; outorgou, com exclusividade, ao Presidente da República o poder regulamentar, através da edição do regulamento de execução, em seu artigo 84, inciso IV, e da edição de regulamento autônomo no mesmo artigo, inciso VI, só permitindo a delegação nessa última hipótese; previu a possibilidade de delegação legislativa na hipótese única das leis delegadas disciplinadas pelo artigo 68, estabelecendo os limites materiais, deixando ao Congresso Nacional a tarefa de realizar a delegação através de Resolução, e fixando os termos e conteúdos de seu exercício; e determinou os limites da edição de Medidas Provisórias com força de lei no artigo 62. (DI PIETRO, Limites da Função..., p. 51-2). 
norma; b) no artigo 87, parágrafo único, inciso II, deu competência aos Ministros de Estado para expedir instruções para a execução das leis, decretos e regulamentos; c) no artigo 207 , estabeleceu a autonomia das Universidades quanto a determinados aspectos que especifica; d) no artigo 21 , inciso XI, previu o órgão regulador das telecomunicações - ANATEL; e e) no artigo 177 , parágrafo $2^{\circ}$, inciso III, dispõe sobre o órgão regulador do monópolio do petróleo - ANP. ${ }^{20}$ Assim, quando a Constituição quis, ela deu competência normativa a órgãos administrativos, não havendo fundamento para presumir igual outorga a outras entidades não alcançadas pelo texto constitucional. ${ }^{21}$

Alega que, com exceção da ANATEL e da ANP, as demais agências não têm previsão constitu- cional, o que significa que a delegação de poderes está sendo realizada pela lei instituidora da agência. Por isso mesmo, a função normativa que exercem não pode, sob pena de inconstitucionalidade, ser superior à exercida por qualquer outro órgão administrativo ou entidade da Administração Indireta. Elas nem podem regular qualquer matéria, no sentido previsto para as agências norte-americanas, nem podem regulamentar leis, pois essa competência é privativa do Chefe do Poder Executivo. Caso pudesse ser objeto de delegação, essa teria que ser efetuada pela autoridade que detém o poder regulamentar e não pelo legislador. ${ }^{22}$ Igualmente não podem regular matéria não disciplinada em lei, pois não há previsão de regulamentos autônomos no direito brasileiro. ${ }^{23,24}$

20 Ibidem, p. 52.

21 Ibidem, p. 52.

22 DI PIETRO, Parcerias na Administração..., p. 156-7.

23 DI PIETRO, Maria Sylvia Zanella. Direito Administrativo. 14. ed. São Paulo: Atlas, 2002.p. 407.

24 Doutrinariamente, admitem-se dois tipos de regulamentos: o regulamento executivo e o regulamento autônomo ou independente. O primeiro complementa a lei, contém normas para a fiel execução da lei, nos termos do artigo 84, inciso IV, da Constituição, não podendo estabelecer normas contra ou ultra legem. Não é possível ao regulamento inovar na ordem jurídica, criando direitos, obrigações, proibições ou sanções, em razão do princípio da legalidade, devendo limitar-se a estabelecer normas sobre a forma como a lei vai ser cumprida pela Administração. Já os regulamentos autônomos podem inovar na ordem jurídica, porque estabelecem normas sobre matérias não disciplinadas em lei, ou seja, ele não completa nem desenvolve nenhuma lei anterior. (DI PIETRO, Parcerias na Administração..., p. 151). 
Relativamente à ANATEL e à ANP, Di Pietro reconhece sua função reguladora, pois se trata de entidades previstas na Constituição como órgãos reguladores. Entretanto, afirma não se poder entender que esses órgãos exercem função legislativa propriamente dita, com possibilidade de inovar a ordem jurídica, uma vez que isso vai de encontro aos princípios da separação dos Poderes e da legalidade. Quando se refere a órgão regulador, a Constituição reconhece ao mesmo a possibilidade de regulamentar a lei a partir de conceitos genéricos, tais como no direito norte-americano. Além disso, as matérias que podem ser objeto de regulamentação são somente aquelas que dizem respeito aos contratos de concessão, respeitados os parâmetros e princípios estabelecidos em lei, não lhes sendo permitido invadir matéria de competência do legislador. ${ }^{25}$ Dessa forma, sua competência reguladora limita-se às relações entre os particulares que estão em situação de sujeição especial ao Estado. ${ }^{26}$

No que diz respeito às demais agências, entende que as normas que elas podem editar resumem-se ao seguinte: a) regular a própria atividade da agência através de normas de efeitos internos; b) conceituar, interpretar, ou explicitar conceitos jurídicos indeterminados contidos em lei, sem que haja inovação na ordem jurídica. Essa segunda função explica-se pela natureza técnica e especializada das agências, pois, muitas vezes, a lei faz uso de conceitos jurídicos indeterminados, cujo sentido tem que ser definido por órgãos especializados. Ela não estará inovando a ordem jurídica, mas explicitando o significado de vocábulos contidos na lei. Se, ao exercer essa função, for além do previsto em lei, estará infringindo o princípio da legalidade..$^{27,28}$

25 DI PIETRO, Direito Administrativo..., p. 407.

26 DI PIETRO, Parcerias na Administração..., p. 158.

27 DI PIETRO, op. cit., p. 407.

28 A autora cita o exemplo da Lei $n^{\circ} 9.872 / 99$, que instituiu a Agência de Vigilância Sanitária, dando a ela, em seu artigo $7^{\circ}$, inciso IV, competência para estabelecer normas e padrões sobre "limites de contaminantes, resíduos tóxicos, desinfetantes, metais pesados e outros que envolvam risco à saúde". Assim, a ANVISA, dentro de seus conhecimentos técnicos, vai poder, legalmente, sem promover inovação na ordem jurídica, baixar ato normativo definindo o que são contaminantes, resíduos tóxicos, etc., e estabelecer os respectivos padrões e limites. São conceitos indeterminados que a agência vai tornar determinados. (Ibidem, p. 407). 


\subsection{Diogo de Figueiredo Mo- reira Neto}

Baseado na classificação das espécies básicas de delegação legislativa proposta por Eduardo García de Enterría, ${ }^{29}$ Diogo de Figueiredo Moreira Neto trata da técnica da deslegalização, afirmando que a lei não necessita sequer entrar na matéria de que trata, bastando abrir a possibilidade a outras fontes normativas, estatais ou não, de regulá-la por atos próprios que, obviamente, não serão de responsabilidade do Legislativo, ainda que sobre eles possa continuar a ser exercido um controle político relativo a eventuais exorbitâncias. Assim, citando Gianmario Demuro, o autor conceitua a deslegalização como sendo uma transferência da função normativa sobre matérias determinadas da sede legislativa estatal para outra sede normativa. ${ }^{30}$

29 De acordo com o administrativista espanhol, há três espécies básicas de delegação legislativa: a delegação receptícia, a remissão e a deslegalização. A delegação receptícia consiste na transferência da função legislativa ao Poder Executivo para produzir normas com força de lei, subordinada a um quadro delimitado e a um tempo determinado no ato da delegação. Seu exercício pelo delegatário esgota e consome a delegação, não podendo dela se valer para revogar ou mesmo alterar o texto promulgado, assumindo o Poder Legislativo, como próprio, o conteúdo da norma delegada. Tal espécie de delegação é encontrada na Constituição brasileira em seu artigo 59, inciso IV, c/c artigo 68, que trata das leis delegadas, estabelecendo seus limites formais e materiais, submetendo-as, em seu artigo 49, inciso $\mathrm{V}$, ao veto legislativo, ou seja, a um controle político do Congresso em caso de exorbitância dos limites da delegação. Já a delegação remissiva pode ser definida como uma remessa que a lei faz a uma normatividade ulterior que deverá ser elaborada pela Administração, sem força de lei, igualmente dentro do quadro substantivo determinado pela própria lei remetente. Seu exercício pelo delegatário não consome nem esgota a delegação remissiva, que poderá ser por ele álterada ou revogada a qualquer tempo, mesmo porque o Legislativo não assume como próprio o conteúdo da norma delegada. Esta instituição, em nosso ordenamento jurídico, corresponde ao poder regulamentar atribuído tradicional e privativamente ao Chefe do Poder Executivo para expedir regulamentos, visando à fiel execução das leis, segundo o artigo 84, inciso IV, da Constituição da República. Quanto à deslegalização, advinda da doutrina e da jurisprudência francesas, essa pode ser conceituada como a retirada pelo próprio legislador de certas matérias do domínio da lei, passando-as ao domínio do regulamento. Dessa maneira, entendese que o titular de um determinado poder não tem dele a disposição, mas tão-somente $o$ exercício. (MOREIRA NETO, Diogo de Figueiredo. Mutações do Direito Administrativo. 2. ed. atualizada e ampliada. Rio de Janeiro: Renovar, 2001, p. 166-7).

30 Ibidem, p. 166-7. 
Afirma Moreira Neto que o conteúdo válido das normas editadas pelas agências está integralmente definido na margem de escolha técnico-científica que a legislação delegante abriu à exclusiva discrição dos respectivos agentes técnicos. ${ }^{31}$ Ultrapassar os limites determinados, ao acrescentar às normas reguladoras critérios políticoadministrativos onde não deveriam existir, caracteriza a invasão de poderes que são próprios à esfera das decisões do Legislativo. ${ }^{32}$

Relativamente à deslegalização no Brasil, afirma que essa recebeu, desde logo, em nível constitucional, um amplo campo de aplicação, em razão da expressa previsão, no artigo 22 , parágrafo único, da Constituição Federal, de demissão federal do poder de legislar sobre matérias específicas ali elencadas, possibilitando a transferência à sede legislativa

31 Destaca que qualquer delegação de funções reguladoras encontra as seguintes ordens de limitação: a) limitações de ordem externa: são as mesmas que submetem qualquer ato normativo, legislativo ou não, a um determinado sistema jurídico, ou seja, a norma sob exame deve se harmonizar com as normas de hierarquia superior e com aquelas de igual hierarquia normativas, não opondo a elas qualquer contraditoriedade; b) limitações de ordem interna: são aquelas que submetem uma norma derivada, como o são as produzidas no exercício das modalidades de delegação, aos parâmetros definidos na norma delegante. Esses parâmetros podem ser formais, estabelecendo limites procedimentais e temporais a serem observados pelas normas reguladoras produzidas pelas agências, não oferecendo maiores dificuldades para a determinação de sua violação, ou materiais, fixando o conteúdo substantivo das normas a serem editadas pelas agências reguladoras. A eventual violação dos parâmetros materiais poderá causar a desvalidação da norma reguladora por usurpação de poder. (Ibidem, p. 167-8).

32 Especifica o autor a diferença existente entre as espécies de discricionariedade, definindo que a discricionariedade político-administrativa geralmente é de amplo espectro de alternativas válidas, que devem ser avaliadas por políticos e burocratas, enquanto que a discricionariedade técnica geralmente comporta opções mais restritas e que devem ser consideradas à luz de regras científicas para que se determine a melhor escolha. Ressalva que a discricionariedade técnica existe somente quando a decisão que nela se fundar possa também ser motivada tecnicamente, asseverando que esta é a limitação mais importante, pois afasta, ao mesmo tempo, o arbítrio, o erro, a impostura e a irrazoabilidade, limite este que afasta a ocorrência de decisões desnecessárias, inadequadas e desproporcionais. (Ibidem, p. 167-9). 
estadual, estabelecendo que o ato de delegação seja uma lei complementar. ${ }^{33}$

Após examinar as hipóteses constitucionais de deslegalização, passa a analisar as hipóteses legais, afirmando que, na Constituição anterior à vigente, tal instituto não tinha a autonomia que hoje lhe é reconhecida, embora existissem inúmeras delegações legais a órgãos administrativos. Tantas eram as delegações que o constituinte de 1988 revogou expressamente no artigo 25 do Ato das Disposições Constitucionais Transitórias todos os dispositivos legais que atribuíssem ou delegassem a órgão do Poder Executivo competência assinalada pela Constituição ao Congresso Nacional. ${ }^{34}$ Entende o autor que, como não proibiu genericamente a delegação, pretendeu o legislador constituinte reestruturar, a partir da nova ordem jurídica do país, todas as hipóteses de deslegalização, o que efetivamente vem acontecendo a partir de então, tanto em nível constitucional quanto legal. Ao se reconhecer que o instituto da deslegalização é proibido, sustenta que se está aceitando uma redução de poderes do Congresso para dispor,

33 Moreira Neto cita outros exemplos de deslegalização constitucional, quais sejam: a) em seu artigo 217 , inciso I e $\S 1^{\circ}$, a Constituição operou a deslegalização da matéria de desportos, reconhecendo a autonomia do setor privado não só para regular a matéria esportiva, mas também para dirimir os conflitos de interesses específicos; b) em seu artigo $220, \S \S 3^{\circ} \mathrm{e} 4^{\circ}$, a Constituição limitou o poder legiferante do Estado apenas às hipóteses expressamente previstas neste dispositivo, in verbis: $\S 3^{\circ}$ - Compete à lei federal: I - regular as diversões e espetáculos públicos, cabendo ao Poder Público informar sobre a natureza deles, as faixas etárias a que não se recomendem, locais e horários em que sua apresentação se mostre inadequada; II - estabelecer os meios legais que garantam à pessoa e à familia a possibilidade de se defenderem de programas ou programações de rádio e televisão que contrariem o disposto no art. 221, bem como da propaganda de produtos, práticas e serviços que possam ser nocivos à saúde e ao meio ambiente. $\S 4^{\circ}$ - A propaganda comercial de tabaco, bebidas alcoólicas, agrotóxicos, medicamentos e terapias estará sujeita a restrições legais, nos termos do inciso II do parágrafo anterior, e conterá, sempre que necessário, advertência sobre os maleficios decorrentes de seu uso.; c) a Emenda Constitucional $n^{\circ} 8$ previu a existência de um órgão regulador autônomo para exercer funções normativas sobre os serviços de telecomunicação (artigo 21, inciso XI); e d) através da Emenda Constitucional ${ }^{\circ} 9$ foi estabelecida a criação de um órgão regulador autônomo para exercer funções normativas sobre o monopólio do petróleo da União (artigo 177, § $2^{\circ}$, inciso III). (MOREIRA NETO, Mutações do Direito..., p. 170-1).

34 Ibidem, p. 170-1. 
conforme a matéria e as circunstâncias, sobre como deverá exercer sua própria competência. ${ }^{35}$

\subsection{Alexandre Santos de Aragão}

Sustenta o renomado autor que as leis atributivas de poder normativo às entidades reguladoras independentes possuem baixa densidade normativa, a fim de propiciar o desenvolvimento de ordenamentos setoriais com aptidão para regular a complexa e dinâmica realidade social subjacente, com autonomia e agilidade. O legislador limita-se a fixar poucos princípios, sobretudo a indicar os valores a serem perseguidos pelos órgãos reguladores, conferindo-lhes uma discricionariedade consideravelmente ampla para preencher os espaços deixados pela lei e para desenvolver os princípios nela estabelecidos. A lei, portanto, sem dar início a uma normatização mais completa, e, muito menos, exaustiva da matéria, estabelece apenas parâmetros bem gerais da regulamentação a ser feita pelo ente regulador independente. ${ }^{36}$

Essas leis integram a categoria das leis-quadro (lois-cadre) ou standartizadas, próprias das matérias de particular complexidade técnica e dos setores suscetíveis a constantes mudanças econômicas e tecnológicas. As leis com essas características não dão maiores elementos pelos quais o administrador deva pautar a sua atuação concreta ou regulamentar, referindo-se genericamente a valores morais, políticos e econômicos existentes no seio da sociedade (saúde pública, utilidade pública, competição no mercado, preços abusivos, continuidade dos serviços públicos, regionalização, etc.). Assim, confere à Administração Pública um grande poder de integração do conteúdo da vontade do legislador.

35 Como reforço desta interpretação, cita o administrativista a deslegalização operada pela Lei n $n^{\circ}$ 9.427/96, que criou a Agência Nacional de Energia Elétrica-ANEEL, como autarquia sob regime especial, com a finalidade, entre outras de regular a produção, transmissão, distribuição e comercialização de energia elétrica. Como outro exemplo de deslegalização limitada operada por lei, desta vez não com o cometimento de poderes normativos a entidades públicas, mas sim a entidades privadas de colaboração, cita os Conselhos Federais das Profissões, na qualidade de delegados de funções reguladoras secundárias, derivadas a partir das respectivas normas reguladoras primárias, que devem ser provenientes do Poder Legislativo, uma vez que disciplinam matérias indelegáveis, objeto de reserva legal (artigo $5^{\circ}$, inciso XIII, da Constituição da República). (Ibidem, p. 172).

36 ARAGÃO, Alexandre Santos de. As Agências Reguladoras Independentes e a Separação de Poderes: Uma Contribuição da Teoria dos Ordenamentos Setoriais. Revista Diálogo Jurídico. Salvador: [s.n.] n. 13, 2002. Disponível em: $<$ www.direitopublico.com.br>. Acesso em: junho de 2005. 
O objetivo das leis assim formuladas é introduzir uma vagueza que permita o trato de fenômenos sociais, muito fugazes para se prestarem ao aprisionamento em uma regra precisa. ${ }^{37}$

Ressalta que a referência aos "quadros estabelecidos pela lei", não se refere apenas a determinado diploma legislativo, mas sim ao conjunto do ordenamento jurídico, pois é esse que, explícita ou implicitamente, em seu sistema, confere às agências independentes poder regulamentar sobre determinada matéria, não nos sendo dado ficar presos apenas à letra da lei..$^{38}$

Citando Eduardo Garcia de Enterría, passa a tratar do instituto da delegificação ou deslegalização, que é definido como a operação efetuada por uma lei que, sem entrar na regulação material do tema, até então regulado por uma lei anterior, abre tal tema à disponibilidade do poder regulamentar da Administração. Mediante o princípio do contrarius actus, quando uma matéria está regulada por determinada lei se produz um congelamento do grau hierárquico normativo que regula a matéria, de modo que apenas por outra lei contrária poderá ser inovada tal regulação. Uma lei de deslegalização opera como contrarius actus da anterior lei de regulação material, porém, não para inovar diretamente essa regulação, mas para degradar formalmente o grau hierárquico da mesma de modo que, a partir de então, possa vir a ser regulada por simples regulamentos. Desse modo, simples regulamentos poderão inovar e, portanto, revogar leis formais anteriores, operação que não seria possível se não existisse previamente a lei degradadora. ${ }^{39}$

Destaca, ainda, que a lei de deslegalização não é uma lei de regulação material, nem uma norma diretamente aplicável como norma agendi, ou uma lei cujo conteúdo deva simplesmente ser completado. É, pois, uma lei que limita seus efeitos a abrir aos regulamentos a possibilidade de entrar em uma matéria até então regulada por lei, ressalvadas as matérias resguardadas por reserva absoluta de lei formal, como são, no Direito brasileiro, as matérias penal e tributária. ${ }^{40}$

Por este entendimento, não há qualquer inconstitucionalidade na delegificação, que não consistiria propriamente em uma transferência de poderes legislativos, mas apenas na adoção, pelo próprio legislador, de uma política legislativa pela qual transfere a uma outra sede normativa a regulação de determinada matéria. Entende que, se o legislador tem poder para revogar

37 Ibidem.

38 Ibidem.

39 ARAGÃO, As Agências Reguladoras... 40 Ibidem. 
uma lei anterior, por que não o teria para, simplesmente, rebaixar o seu grau hierárquico ${ }^{41}$

Observa que o Poder Legislativo, face à complexidade, dinamismo e tecnicização da sociedade, tem distinguido os aspectos políticos dos de natureza preponderantemente técnica da regulação social, retendo os primeiros, mas, consciente das suas naturais limitações, transpassando a outros órgãos ou entidades, públicas ou privadas, a normatização de cunho marcadamente técnico. Porém, mesmo nestes casos resguarda o Poder Legislativo o balizamento e a coordenação destas regulações plurifórmicas e pluricêntricas. ${ }^{42}$

Assim, conclui que a necessidade de descentralização normativa, principalmente de natureza técnica, é a razão de ser das entidades reguladoras independentes. ${ }^{43}$

\subsection{Egon Bockmann Moreira}

O autor reconhece que a maioria da doutrina brasileira, ao interpretar a Constituição, não admite a possibilidade de inovações normativas através de regulamentos, cabendo a esses apenas dar pura execução às normas previamente existentes. No entanto, discorda desse posicionamento majoritário, entendendo que, em face da tremenda complexidade e da aceleração dinâmica dos fenômenos político-sociais da atualidade, é possível a edição de regulamentos autônomos no direito brasileiro, decorrendo esta faculdade regulamentar do dever que tem a Administração Pública de organizar e tornar plausivelmente efetiváveis as atribuições que lhe são próprias. Dessa forma, defende que a necessidade impõe o caráter normativo das agências reguladoras, pois a instabilidade dos mercados, em conjunto com a evolução do fenômeno políticoeconômico mundial, impõe que a Administração disponha de meios jurídicos que a tornem apta a regular imediatamente a conjuntura econômica. ${ }^{44}$

Justifica sua teoria utilizando-se dos argumentos de Eros Roberto Grau, que defende a distinção entre função normativa e função legislativa: esta se vincula a uma perspectiva subjetiva, decorrente da adoção do sistema de divisão dos Poderes confiada a determinados órgãos predispostos para a tarefa suprema de constituir (integrar) o ordenamento jurídico; ao passo que aquela abstrai o vínculo subjetivo e emana puras estatuições primárias seja em decorrência do exercício de

\section{Ibidem.}

42Ibidem.

43 Ibidem.

44 MOREIRA, Egon Bockmann. Agências Administrativas, Poder Regulamentar e o Sistema Financeiro Nacional. Revista de Direito Administrativo. Rio de Janeiro: [s.n.] v. 218 , p. 102-105, out./dez. 1999. 
poder originário para tanto, seja em decorrência de poder derivado - contendo preceitos abstratos e genéricos. ${ }^{45}$

Ademais, discorre que, apesar de o Poder Legislativo deter competência exclusiva para elaborar leis, não a detém, com essa qualidade, para editar normas. O jurista alerta para que se entenda como função normativa a de emanar instituições primárias, seja em função do exercício do poder originário para tanto, seja em decorrência de poder derivado, contendo preceitos abstratos e genéricos. Ressalta que o poder regulamentar tem fundamento na atribuição de poder normativo, e não em suposta delegação de função legislativa ou poder discricionário, não encontrando óbices no princípio da legalidade, uma vez que a Administração pode produzir atos normativos de caráter não legislativo, no desenvolvimento de função normativa, não legislativa. ${ }^{46}$

Dessa forma, conclui serem válidos os regulamentos autônomos ou independentes editados pelas agências reguladoras, pois emanados a partir de atribuição implícita do exercício de função normativa ao Executivo, definida na Constituição, ou derivada de sua estrutura. ${ }^{47}$

45 MOREIRA, Agências Administrativas..., p. 104.

46 Ibidem.

47 A partir da teoria de Grau, sustenta Egon Bockmann Moreira que o regulamento autônomo desenvolve-se em dois ambientes normativos: na área não expressamente reservada à lei ou na chamada reserva da Administração, ou seja, aquela em que, por disposição de lei maior, é livre, discricionário e exclusivo o desenrolar da ação administrativa. Entende que no primeiro caso a superveniência de lei revogará o regulamento, já na segunda hipótese, afirma que a iniciativa legislativa padecerá de insanável ilegitimidade. O regulamento autônomo não poderá contrariar a lei, ainda que implique em criação de disposição normativa. lgualmente não poderá criar, de maneira inédita e autônoma, sem qualquer lastro normativo, obrigações e deveres às pessoas privadas. Entretanto, entende ser possível os regulamentos gerarem deveres, direitos e obrigações, desde que expressa e previamente autorizados por lei, ainda que de modo abstrato. Da mesma forma, não é permitido aos regulamentos a criação de penas, sanções ou tributos, em virtude dos princípios da tipicidade penal e tributária. Além disso, deve o regulamento respeitar a divisão de competências entre as pessoas componentes da Federação, sendo impossível a invasão dos limites determinados pela Constituição. Afirma, ainda, que os regulamentos não podem restringir a atividade econômica privada, subordinando seu exercício à expedição de prévia autorização por parte dos órgãos públicos, exceto nos casos previstos em lei, de acordo com o artigo 170, parágrafo único, da Constituição da República. Também não é cabível que os regulamentos tenham efeitos retroativos, a não ser quando visem a beneficiar pessoas privadas, alegando, ainda, que os regulamentos deverão ser fundamentados, obedecendo à indispensável motivação pública, de fato e de direito, contemporânea à sua edição. Por fim, destaca que os regulamentos autônomos serão sempre passíveis de controle pelo Poder Judiciário, relativamente à possibilidade de sua emanação, bem como quanto ao conteúdo de suas disposições. (MOREIRA, Agências Administrativas..., p. 102-5). 


\subsection{Alexandre de Moraes}

Entende o autor que as agências reguladoras podem receber do Poder Legislativo, através de lei de iniciativa do Executivo, uma delegação para exercerem seu poder normativo de regulação, cabendo ao Congresso Nacional a fixação das finalidades, dos objetivos básicos e da estrutura das agências, competindo-lhe ainda a fiscalização de suas atividades. ${ }^{48}$

De acordo com essa teoria, o Congresso Nacional permanecerá com a centralização governamental, uma vez que tem o poder de decidir politicamente sobre a delegação e seus limites às agências de regulação. No entanto, efetivará a descentralização administrativa, permitindo o exercício do poder normativo para a obtenção dos objetivos determinados na lei. ${ }^{49}$

Afirma Moraes que o Legislativo poderá, da mesma forma que no mode- lo norte-americano, instituir os parâmetros básicos, mediante a utilização de conceitos genéricos - standards -, cabendo às agências a atribuição de regulação específica, já que passarão a exercer, exclusivamente, uma atividade gerencial e fiscalizatória que, tradicionalmente no Brasil, sempre correspondeu à Administração Direta, enquanto cedente dos serviços públicos através de permissões ou concessões. ${ }^{50}$

Ressalta o autor que esse deslocamento de atividades decisórias e regulatórias da Administração Direta para as agências reguladoras será obrigatoriamente feito por lei, de iniciativa do Poder Executivo, e deve estar relacionado à promoção de eficiência, à defesa do mercado e das liberdades econômicas das pessoas vinculadas à prestação de serviços públicos, ao lado da justa e razoável fixação das tarifas para garantir o equilíbrio econômicofinanceiro da concessionária. ${ }^{51}$

48 MORAES, Alexandre de. Agências Reguladoras. Revista dos Tribunais. São Paulo: [Revista dos Tribunais] v. 791, set. 2001, p. 744.

49 Ibidem, p. 744.

50 Ibidem, p. 744.

51 Ademais, ressalta que a lei estabelecerá os parâmetros da atuação das agências, conferindo suas atribuições administrativas diretamente vinculadas à regulação e fiscalização dos serviços relacionados com os contratos de concessão ou permissão de sua respectiva área, inclusive sobre a fixação de tarifas e a aplicação de penalidades, previamente previstas em lei e mediante procedimento administrativo, garantida a ampla defesa e o devido processo legal, de acordo com o disposto no artigo $5^{\circ}$, inciso LV, da Constituição Federal. Afirma ser absolutamente vedado as agências atuarem em desrespeito às normas legais definidoras de suas funções, pois, não possuem um cheque em branco para agir como bem entendem, divorciadas do princípio da legalidade, uma vez que estão vinculadas a tal princípio por submissão aos comandos legais direcionados à Administração Pública Direta e Indireta. Também não lhes é permitido que editem atos normativos que inovem o ordenamento jurídico, isto é, que regulem matéria para a qual inexista um prévio conceito genérico em sua lei instituidora, nem tampouco poderão criar ou aplicar sanções não previstas em lei. (MORAES, Agências Reguladoras..., p. 745). 


\section{CONCLUSÃO}

Ainda há um longo caminho a ser trilhado para que se atinja um consenso acerca da possibilidade de atribuição de poderes normativos às agências reguladoras no Brasil. Todavia, há uma certa tendência a aceitar-se a função reguladora, pois, tem se reconhecido a necessidade de órgãos especializados para a produção de normas eminentemente técnicas, principalmente porque se admite as limitações do Poder Legislativo para editar tais normas, que necessitam de estudos maiores para a sua elaboração. Além disso, com as crescentes mudanças no campo da tecnologia,

\section{REFERÊNCIAS}

ARAGÃO, Alexandre Santos de. As Agências Reguladoras Independentes e a Separação de Poderes: uma contribuição da teoria dos ordenamentos setoriais. Revista Diálogo Jurídico. Salvador: [s.n.] n. 13, 2002. Disponível em: $<w w w . d i r e i t o p u b l i c o . c o m . b r>$. Acesso em: junho de 2005.

BARROSO, Luís Roberto. Agências Reguladoras. Constituição, Transformações do Estado e Legitimidade Democrática. In: MOREIRA NETO, Diogo de Figueiredo (Coord.). Uma Avaliação das Tendências Contemporâneas do Direito Administrativo. Rio de Janeiro: Renovar, 2003. p. 159-193. seria inadequada a regulação de matérias técnicas por via de lei, que exigem um processo mais formal e demorado, e, conseqüentemente, também necessitam de um processo formal para serem alteradas, impedindo que as normas acompanhem as evoluções tecnológicas.

Cumpre por fim ressaltar que o exercício de função normativa pelas agências não fere os princípios da legalidade e da separação dos Poderes, haja vista que é imprescindível que a Administração Pública disponha de um espaço de atuação que possibilite escolhas e decisões razoáveis, para que possa atingir seu principal objetivo, que é a satisfação do interesse público.

CARVALHO, Vinícius Marques. Desregulação e Reforma do Estado no Brasil: impacto sobre a prestação de serviços públicos. In: DI PIETRO, Maria Sylvia Zanella (Org.). Direito Regulatório. Belo Horizonte: Fórum, 2003. p. 157-75.

DI PIETRO, Maria Sylvia Zanella. Direito Administrativo. 14. ed. São Paulo: Atlas, 2002.

DI PIETRO, Maria Sylvia Zanella. Limites da Função Reguladora das Agências diante do Princípio da Legalidade. In: DI PIETRO, Maria Sylvia Zanella (Org.). Direito Regulatório. Belo Horizonte: Fórum, 2003. p. 27-60. 
DI PIETRO, Maria Sylvia Zanella. Parcerias na Administração Pública. 4. ed. São Paulo: Atlas, 2002.

GUERRA, Glauco Martins. Agências Reguladoras no Brasil: princípio da legalidade e regulação. In: DI PIETRO, Maria Sylvia Zanella (Org.). Direito Regulatório. Belo Horizonte: Fórum, 2003. p. 323-68.

MEIRELLES, Hely Lopes. Direito Administrativo Brasileiro. 29. ed. atual. por Eurico de Andrade Azevedo, Délcio Balesteto Aleixo e José Emmanuel Burle Filho. São Paulo: Malheiros, 2004.

MORAES, Alexandre de. Agências Reguladoras. Revista dos

\section{REFERÊNCIAS LEGISLATIVAS}

BRASIL. Constituição da República Federativa do Brasil, de 05 de outubro de 1988. Disponível em: $<$ http://www.planalto.gov.br $>$. Acesso em: junho/2005.

BRASIL. Lei ${ }^{\circ}$ 9.427/96, de 26 de dezembro de 1996. Disponível em: $<$ http://www.planalto.gov.br>. Acesso em: junho/2005.

BRASIL. Lei ${ }^{\circ} 9.472 / 97$, de 16 de julho de 1997. Disponível em: $<\mathrm{http}$ / /www.planalto.gov.br>. Acesso em: junho/2005.
Tribunais. São Paulo: [Revista dos Tribunais] v. 791, p. 739-756, set. 2001.

MORAES, Alexandre de. Direito Constitucional. 10. ed. São Paulo: Atlas, 2001.

MOREIRA, Egon Bockmann. Agências Administrativas, Poder Regulamentar e o Sistema Financeiro Nacional. Revista de Direito Administrativo. Rio de Janeiro: [s.n.] v. 218, p. 93-112, out./ dez. 1999.

NETO, Diogo de Figueiredo Moreira. Mutações do Direito Administrativo. 2. ed. atual. e ampl. Rio de Janeiro: Renovar, 2001.

BRASIL. Lei ${ }^{\circ} 9.478 / 97$, de 06 de agosto de 1997. Disponível em: $<$ http://www.planalto.gov.br>. Acesso em: junho/2005.

BRASIL. Lei ${ }^{\circ} 9.961 / 00$, de 28 de janeiro de 2000. Disponível em: $<$ http://www.planalto.gov.br $>$. Acesso em: junho/2005.

BRASIL. Lei ${ }^{\circ} 9.984 / 00$, de 17 de julho de 2000. Disponível em: $<\mathrm{http}$ :/ /www.planalto.gov.br>. Acesso em: junho/2005. 